STUDIA I PRACE WYDZIAŁU NAUK EKONOMICZNYCH I ZARZĄDZANIA NR 40, T. 2

DOI: $10.18276 /$ sip. $2015.40 / 2-18$

\author{
Jolanta Korkosz-Gębska*
}

Politechnika Warszawska

\title{
SYSTEMY WSPARCIA INNOWACJI EKOLOGICZNYCH POLSKI WSCHODNIEJ
}

\section{STRESZCZENIE}

Polska Wschodnia jest obszarem o najniższym poziomie rozwoju gospodarczego w Polsce i jednym z najsłabszych gospodarczo w Unii Europejskiej. Makroregion stał się przedmiotem szczególnego zainteresowania polityki regionalnej, wymagającym podejmowania dodatkowych działań, przyczyniających się do zdynamizowania jego rozwoju. Inteligentny, zrównoważony oraz sprzyjający włączeniu społecznemu rozwój Polski Wschodniej możliwy jest dzięki wykorzystaniu inteligentnych specjalizacji regionu, wśród których znajdują się m.in. innowacje ekologiczne. Celem artykułu jest identyfikacja systemów wsparcia innowacji ekologicznych w analizowanym regionie oraz ocena możliwości wykorzystania ekoinnowacyjności w budowaniu przewagi konkurencyjnej Polski Wschodniej.

Słowa kluczowe: zrównoważony rozwój, innowacje ekologiczne, Polska Wschodnia

\section{Wprowadzenie}

Strategia „Europa 2020” wyznaczyła nowy sposób prowadzenia polityki regionalnej państw członkowskich. Komisja Europejska zaproponowała 7 projektów przewodnich, umożliwiających realizację każdego z priorytetów tematycznych. Jednym z nich jest „Unia innowacji”, którego celem jest wykorzystywanie działalności badawczo-rozwojowej i innowacyjnej do rozwiązywania takich problemów, jak

\footnotetext{
*Adres e-mail: j.korkosz@wip.pw.edu.pl.
} 
zmiany klimatu, efektywność energetyczna, zdrowie oraz zmiany demograficzne ${ }^{1}$. Innowacje ekologiczne wpisują się w priorytety strategii i flagowych inicjatyw UE, które poprzez działania w ramach inteligentnych specjalizacji mogą zapewnić podążanie ścieżką inteligentnego, zrównoważonego oraz sprzyjającego włączeniu społecznemu rozwoju. Jest to szczególnie widoczne w województwach Polski Wschodniej, w których za inteligentne specjalizacje regionu przyjęto właśnie innowacje ekologiczne.

Celem artykułu była identyfikacja systemów wsparcia innowacji ekologicznych w województwach Polski Wschodniej oraz ocena możliwości wykorzystania ekoinnowacyjności w budowaniu przewagi konkurencyjnej regionu. W opracowaniu wykorzystano badania i raporty instytucji badawczych, rządowych, jak również informacje umieszczone na stronach internetowych przedsiębiorstw i instytucji pozarządowych w oparciu o metodę desk research.

\section{Strategia rozwoju społeczno-gospodarczego Polski Wschodniej}

W skład makroregionu Polski Wschodniej wchodzą województwa: lubelskie, podkarpackie, podlaskie, świętokrzyskie i warmińsko-mazurskie. Łączy je niezadowalająca sytuacja społeczno-gospodarcza, przekładająca się na najniższy poziom rozwoju gospodarczego w Polsce. Województwa te należą do regionów nisko zurbanizowanych, słabo uprzemysłowionych i słabo zagospodarowanych infrastruktural$n^{n i}{ }^{2}$. Polityka regionalna ukierunkowana jest na podejmowanie działań umożliwiających nadrobienie opóźnień i zdynamizowanie rozwoju makroregionu, co w konsekwencji ma wpłynąć na zwiększenie spójności społecznej, gospodarczej i przestrzennej całego kraju. Przejawem takiego podejścia było przyjęcie przez Radę Ministrów w 2008 roku Strategii Rozwoju Społeczno-Gospodarczego Polski Wschodniej do roku 2020. Polska Wschodnia stała się również istotnym beneficjentem europejskiej polityki spójności w ramach Programu Operacyjnego Rozwój Polski Wschodniej 2007-2014 oraz Programu Operacyjnego Polska Wschodnia 2014-2020.

W Krajowej Strategii Rozwoju Regionalnego 2010-2020: Regiony, Miasta, Obszary Wiejskie, makroregion Polski Wschodniej ,został zidentyfikowany jako jedyny

${ }^{1}$ Komisja Europejska, Europa 2020. Strategia na rzecz inteligentnego i zrównoważonego rozwoju sprzyjajacego właczeniu społecznemu, Bruksela 2010, s. 14.

2 J. Szafran, Polska Wschodnia w polityce spójności Unii Europejskiej, w: Rozwój Polski Wschodniej. Ograniczenia i wyzwania, red. B. Jóźwik, M. Sagan, Difin, Warszawa 2012, s. 47. 
w Polsce obszar problemowy o znaczeniu krajowym, wobec którego ukierunkowana interwencja rozwojowa powinna być realizowana przy szczególnym, dodatkowym wsparciu z poziomu centralnego" ${ }^{3}$. Do szans rozwojowych, których właściwe wykorzystanie może przyczynić się do poprawy pozycji rozwojowej makroregionu, należą 3 strategiczne obszary: innowacyjność, zasoby pracy i infrastruktura ${ }^{4}$.

Zgodnie z unijnymi wytycznymi, w okresie nowej perspektywy finansowej każdy region powinien posiadać Strategię Badań i Rozwoju na rzecz Inteligentnej Specjalizacji (Regional Innovation Strategies for Smart Specialisation - RIS3) ${ }^{5}$. Inteligentne specjalizacje można określić jako ,przedsiębiorczy proces identyfikacji obszarów nauki i technologii, ze specjalizacji, w których może korzystać wybrany region"'. Inteligentne specjalizacje Polski Wschodniej przedstawiono w tabeli 1.

Tabela 1. Inteligentne specjalizacje województw Polski Wschodniej w ramach strategii RIS3

\begin{tabular}{|c|c|c|c|c|}
\hline Lubelskie & Podkarpackie & Podlaskie & Świętokrzyskie & $\begin{array}{l}\text { Warmińsko- } \\
\text {-mazurskie }\end{array}$ \\
\hline $\begin{array}{l}\text { - ICT, multimedia, } \\
\text { - biogospodarka, } \\
\text { - medycyna i tury- } \\
\text { styka zdrowotna, } \\
\text { - energetyka } \\
\text { (w tym OZE) }\end{array}$ & $\begin{array}{l}\text { - ICT, multimedia, } \\
\text { - wysoka jakość } \\
\text { życia, } \\
\text { - lotnictwo i kos- } \\
\text { monautyka }\end{array}$ & $\begin{array}{l}\text { - biogospodarka, } \\
\text { - brama na } \\
\text { Wschód. }\end{array}$ & $\begin{array}{l}\text { - zdrowa żyw- } \\
\text { ność, } \\
\text { - medycyna } \\
\text { i turystyka zdro- } \\
\text { wotna, } \\
\text { - przemysł ma- } \\
\text { szynowy i meta- } \\
\text { lowy }\end{array}$ & $\begin{array}{l}- \text { zdrowa żyw- } \\
\text { ność, } \\
\text { - ekonomia wody, } \\
\text { - przemysł drzew- } \\
\text { ny i meblarski }\end{array}$ \\
\hline
\end{tabular}

Źródło: opracowanie własne na podstawie: W. Dziemianowicz, J. Szlachta, K. Peszat, Potencjały rozwoju i specjalizacje polskich województw, Geoprofit, Warszawa 2014, s. 74-75.

Do inteligentnych specjalizacji województw Polski Wschodniej należą innowacje ekologiczne. W przypadku Podkarpacia można je odnaleźć w segmencie „wysoka jakość życia”, obejmującym m.in. produkcję i przetwórstwo żywności najwyższej jakości biologicznej i zdrowotnej, ekologiczne i zrównoważone rolnictwo

${ }^{3}$ Ministerstwo Rozwoju Regionalnego, Strategia rozwoju społeczno-gospodarczego Polski Wschodniej do roku 2020, Warszawa 2013, s. 9.

${ }^{4}$ Ibidem, s. 13.

${ }^{5}$ Portal Innowacji, Inteligentne specjalizacje a klastry, www.pi.gov.pl/PARP/chapter_86197.asp?so$\mathrm{id}=427438326 \mathrm{EDF} 45 \mathrm{~A} 2935940951 \mathrm{~F} 4 \mathrm{~B} 3475$ (dostęp 2.05.2015).

${ }^{6}$ D. Foray, ERA: Entrepreneurial Regional Action, in public service review, „Science \& Technology” 2009, No. 2, s. 44-47. 
i przetwórstwo, produkty regionalne i tradycyjne, zrównoważoną i odpowiedzialną turystykę, zdrowie, eko-technologie?

Innowacyjność uważana jest za determinantę przewagi konkurencyjnej gospodarki regionalnej. Ekologiczny potencjał tkwiący w regionach Polski Wschodniej może zwiększyć ich ekoinnowacyjność, a w konsekwencji doprowadzić do wzrostu konkurencyjności na tle pozostałych regionów w kraju i UE.

\section{Istota innowacji ekologicznych}

„Ekoinnowacje prowadzą do zintegrowanych rozwiązań mających na celu zmniejszenie nakładów zasobów i energii, jednocześnie podnosząc jakość produktu lub usługi. Innowacja technologiczna jest jednym ze sposobów ekoinnowacji”». Innowacje ekologiczne mogą obejmować nowości z zakresu nietechnicznego i technicznego ${ }^{9}$. Pierwsza grupa dotyczy nowości wprowadzonych w przedsiębiorstwie, zmian po stronie użytkownika oraz zmian instytucjonalnych i kulturowych. Innowacje techniczne z kolei można podzielić na innowacje procesowe oraz produktowe ${ }^{10}$. Do procesowych innowacji ekologicznych należą ${ }^{11}$ :

- innowacje addytywne (technologie środowiskowe), które nie są częścią procesu produkcyjnego, lecz stanowią dodatkowe rozwiązanie prowadzące w efekcie do osiągnięcia wymagań środowiskowych, nie likwidując przyczyn powstawania zanieczyszczeń, lecz skutki ich powstawania,

- technologie zintegrowane, będące częścią procesu produkcyjnego, minimalizujące powstawanie zanieczyszczeń „,u źródeł”, co ma przyczynić się do likwidacji i zapobiegania powstawaniu odpadów oraz minimalizowania zużycia zasobów.

${ }^{7}$ Urząd Marszałkowski Województwa Podkarpackiego, Projekt regionalnej strategii innowacji województwa podkarpackiego na lata 2014-2020 na rzecz inteligentnej specjalizacji (RIS3), Rzeszów 2013, s. 34.

${ }^{8}$ M. Carley, P. Spapens, Dzielenie się światem, Instytut na Rzecz Ekorozwoju, Białystok-Warszawa 2000, s. 157.

${ }^{9}$ W. Gerstlberger, M. Will, Rola innowacji ekologicznych, w: Zintegrowane zarządzanie środowiskiem. Systemowe zależności między polityka, prawem, zarządzaniem i technika, red. A. Kryński, M. Kramer, A.F. Caekelbergh, Oficyna a Wolters Kluwer business, Warszawa 2013, s. 498.

${ }^{10}$ OECD, Eurostat, Podręcznik Oslo. Zasady gromadzenia i interpretacji danych dotyczacych innowacji, Paris 2005, s. 15.

${ }^{11}$ A. Leszczyńska, Absorpcja innowacji ekologicznych w przedsiębiorstwie, Wydawnictwo Uniwersytetu Marii Curie-Skłodowskiej, Lublin 2011, s. 36. 
Produktowa innowacja ekologiczna może dotyczyć m.in. ${ }^{12}$ :

- ekologiczności cyklu życia produktu,

- tworzenia proekologicznych rozwiązań prowadzących do zmniejszenia zużycia zasobów naturalnych lub ingerencji w środowisko naturalne,

- tworzenia nowych rozwiązań wspierających ochronę środowiska,

- utylizacji odpadów,

- zwiększenia ekologiczności eksploatacji,

- ekologistyki,

- zwiększenia bezpieczeństwa dla użytkownika.

Ekoinnowacje rozumieć należy jako „wdrożenie do szerokiego wykorzystania: nowych produktów, procesów, sposobów zarządzania oraz urządzeń infrastruktur, których celem jest: ochrona powietrza, wód, gleby, krajobrazu, flory i fauny, a także człowieka oraz minimalizacja, a nawet redukcja występujących w tym zakresie zanieczyszczeń i zagrożeń względem środowiska przyrodniczego"13. Rezultatem wdrażania ekoinnowacji, z punktu widzenia wszystkich grup interesariuszy, jest lepsza jakość życia.

\section{Systemy wsparcia innowacji ekologicznych Polski Wschodniej}

Systemy wsparcia ekoinnowacji mogą obejmować zespół podmiotów, takich jak firmy, organizacje oraz instytucje, które oddziałują na siebie w procesie kreowania, dyfuzji oraz wykorzystania ekoinnowacji. Przykładem takiego systemu są klastry.

W I kwartale 2015 roku na terenie Polski Wschodniej zlokalizowanych było 41 klastrów $^{14}$. Na szczególną uwagę zasługuje Świętokrzysko-Podkarpacki Klaster Energetyczny, od 1 kwietnia 2013 roku funkcjonujący pod nazwą Świętokrzysko-Podkarpacki Klaster Energetyczny - Kontynuacja. Jego celem jest „zbudowanie platformy współpracy ponadregionalnej z zakresu szeroko rozumianego poszanowania energii, a w szczególności: promocja, wdrażanie i upowszechnianie na pozio-

${ }^{12}$ A. Chodyński, Innowacyjność i jakość w strategii rozwoju firmy. Zarządzanie produktowymi innowacjami ekologicznymi, Wydawnictwo Wyższej Szkoły Zarządzania i Marketingu w Sosnowcu, Sosnowiec 2003, s. 104-105.

${ }^{13}$ L. Białoń, Aspekty ekologiczne w działalności innowacyjne, w: Ekonomika i zarzadzanie innowacjami $w$ warunkach zrównoważonego rozwoju, red. A.H. Jasiński, R. Ciborowski, Wydawnictwo Uniwersytetu w Białymstoku, Białystok 2012, s. 198.

${ }^{14}$ Portal Innowacji, Klastry w Polsce, www.pi.gov.pl/PARP/data/klastry/index.html (dostęp 4.05.2015). 
mie lokalnym, regionalnym i ponadregionalnym celów nowej polityki energetycznej Unii Europejskiej, a w szczególności efektywnego wykorzystywania energii”'15.

Misją Lubelskiego Klastra Ekoenergetycznego jest ,wspieranie wszelkich działań związanych ze zrównoważonym wykorzystaniem odnawialnych źródeł energii w oparciu o potencjał województwa lubelskiego poprzez opracowywanie i wdrażanie innowacji technologicznych, produkcyjnych i procesowych oraz popularyzacja odnawialnych źródeł energii w regionie" ${ }^{\prime 16}$.

Działania prowadzone przez Podkarpacki Klaster Energii Odnawialnej koncentrują się wokół „stworzenia silnej i jednolitej reprezentacji interesów przedsiębiorców, inwestorów, jednostek badawczo-rozwojowych i innych podmiotów, działających na rzecz rozwoju ekoenergetyki opartej na odnawialnych źródłach energii”"17.

Klaster Dolina Ekologicznej Żywności jako pierwszy w kraju zrzesza różne podmioty promujące rozwój żywności ekologicznej. Warto zauważyć, iż w jego struktury mogą przystąpić podmioty i organizacje z terenu całej Polski Wschodniej, zainteresowane rozwojem produkcji ekologicznej żywności i popularyzujące prowadzenie zdrowego trybu życia.

Tworzenie innowacji ekologicznych jest także wspierane przez jednostki naukowe, których pracownicy zaangażowani są w realizację regionalnych strategii innowacji oraz edukację z zakresu ekoinnowacyjności. Przykładem może być Katedra Przedsiębiorczości, Zarządzania i Ekoinnowacyjności na Wydziale Zarządzania Politechniki Rzeszowskiej, której kadra zaangażowana jest w prace naukowe Instytutu Zielonej Ekonomii ${ }^{18}$.

Z kolei Wyższa Szkoła Ekonomii i Innowacji w Lublinie zrealizowała projekt „Przedsiębiorczy eko menedżer. Studia podyplomowe z elementami kształcenia na odległość dla realizacji strategii Europa 2020", w ramach którego prowadziła studia podyplomowe związane m.in. z zarządzaniem ekoinnowacjami i wdrożeniem technologii przyjaznych dla środowiska naturalnego w logistyce.

Efektem projektu „Energis - Budynek Dydaktyczno-Laboratoryjny Inżynierii Środowiska, Politechnika Świętokrzyska Kielce” jest inteligentny energooszczędny

${ }^{15}$ Świętokrzysko-Podkarpacki Klaster Energetyczny - kontynuacja, http://klasteroze.it.kielce. $\mathrm{pl} /$ ? id=1 (dostęp 4.05.2015).

${ }^{16}$ Fundacja Rozwoju Lubelszczyzny, LKE, http://fundacja.lublin.pl/index.php/lke (dostęp 4.05.2015).

${ }^{17}$ Podkarpacki Klaster Energii Odnawialnej, O klastrze, http://energia.rzeszow.pl/index.php/pomoc (dostęp 4.05.2015).

18 S. Dziedzic, L. Woźniak, Ekoinnowacje jako priorytetowy kierunek Regionalnej Strategii Innowacji Województwa Podkarpackiego, Politechnika Rzeszowska, Rzeszów 2013, s. 46. 
obiekt, w którym mieści się Wydział Inżynierii Środowiska, Geomatyki i Energetyki. W budynku znajdują się m.in. laboratoria odnawialnych źródeł energii, systemów inteligentnych, wymiany i odzysku ciepła, nano- i ekoinżynierii.

Działania w zakresie ekoinnowacyjności podejmowane są również przez przedsiębiorstwa, które w sposób świadomy wdrażają ekologiczne rozwiązania. Na przykład Zakład Mięsny Smak-Górno Sp. z o.o., realizujący projekt ZERO E, dąży do wytwarzania produktów wolnych od syntetycznych związków chemicznych w ekoinnowacyjny sposób (uprawa wierzby energetycznej, system pozyskiwania i odzyskiwania ciepła). Innym przykładem może być WSK „PZL-Rzeszów” SA, jedna z najbardziej innowacyjnych firm w Polsce, która podejmuje działania w celu zapobiegania zanieczyszczeniom i ochronie środowiska naturalnego, czego dowodem mogą być liczne wyróżnienia (np. nagroda „Lider Polskiej Ekologii” czy „Zieloni Bohaterowie"). W roku 2008 regionalnym liderem innowacyjności była firma INKSPOT D.D. z Olsztyna, wyróżniona tym tytułem za opracowanie technologii produkcji i wprowadzenie na rynek wysokiej jakości kolorowych tonerów do drukarek laserowych z wykorzystaniem recyklingu.

Tworzenie i absorpcja innowacji ekologicznych mogą być także wspierane w ramach licznych inicjatyw krajowych. Przykładem jest konkurs „Ekoodpowiedzialni w biznesie", organizowany przez firmę Abrys. Wszystkie przedsiębiorstwa, które w swoim rozwoju uwzględniają aspekt ochrony środowiska, a także pomysłodawcy innowacyjnych rozwiązań w zakresie technologii środowiskowych, mogą zgłaszać się do konkursu w dwóch kategoriach: „Przedsiębiorstwo” oraz „Innowacje środowiskowe". Wśród laureatów poprzednich edycji znalazła się firma Niczuk-Metall - PL, zlokalizowana w Wilimowie k. Olsztyna.

Innowacje ekologiczne mogą być również promowane w ramach targów branżowych, takich jak Energetics, ENEX, EKOGALA, Poleko, Pellets-EXPO i Brykiet-EXPO i innych.

\section{Podsumowanie}

Ekoinnowacyjność wspiera budowanie przewagi konkurencyjnej Polski Wschodniej. Potencjał do generowania i absorpcji innowacji ekologicznych makroregionu jest duży, co znalazło swoje odzwierciedlenie w wyznaczeniu inteligentnych specjalizacji regionu. Wykorzystanie mocnych stron Polski Wschodniej do zdyna- 
mizowania jej rozwoju odbywać się może poprzez współpracę firm, uczelni i innych organizacji, zwłaszcza w ramach klastrów. Duże znaczenie mają także uczelnie wyższe, które, oprócz kształcenia w zakresie ekoinnowacji, same opracowują i wdrażają innowacyjne rozwiązania. System działań wspierających ekoinnowacje uzupełniany jest o liczne wydarzenia i tematyczne inicjatywy, realizowane na poziomie krajowym i lokalnym. Istnieje duża szansa na to, że przy odpowiednim zarządzaniu regionem, uwzględniającym jego potencjał w zakresie ekoinnowacyjności, Polska Wschodnia poprawi swoją pozycję rozwojową i konkurencyjną na tle innych regionów kraju, jak i Unii Europejskiej.

\section{Literatura}

Białoń L., Aspekty ekologiczne w działalności innowacyjnej, w: Ekonomika i zarzadzanie innowacjami w warunkach zrównoważonego rozwoju, red. A.H. Jasiński, R. Ciborowski, Wydawnictwo Uniwersytetu w Białymstoku, Białystok 2012.

Carley M., Spapens P., Dzielenie się światem, Instytut na Rzecz Ekorozwoju, BiałystokWarszawa 2000.

Chodyński A., Innowacyjność i jakość w strategii rozwoju firmy. Zarzadzanie produktowymi innowacjami ekologicznymi, Wydawnictwo Wyższej Szkoły Zarządzania i Marketingu w Sosnowcu, Sosnowiec 2003.

Dziedzic S., Woźniak L., Ekoinnowacje jako priorytetowy kierunek Regionalnej Strategii Innowacji Województwa Podkarpackiego, Politechnika Rzeszowska, Rzeszów 2013.

Dziemianowicz W., Szlachta J., Peszat K., Potencjały rozwoju i specjalizacje polskich województw, Geoprofit, Warszawa 2014.

Foray D., ERA: Entrepreneurial Regional Action, in public service review, „Science \& Technology" 2009, No. 2.

Fundacja Rozwoju Lubelszczyzny, LKE, http://fundacja.lublin.pl/index.php/lke (dostęp 4.05.2015).

Gerstlberger W., Will M., Rola innowacji ekologicznych, w: Zintegrowane zarzadzanie środowiskiem. Systemowe zależności między polityka, prawem, zarzadzaniem i technika, red. A. Kryński, M. Kramer, A.F. Caekelbergh, Oficyna a Wolters Kluwer business, Warszawa 2013.

Komisja Europejska, Europa 2020. Strategia na rzecz inteligentnego i zrównoważonego rozwoju sprzyjajacego właczeniu społecznemu, Bruksela 2010.

Leszczyńska A., Absorpcja innowacji ekologicznych w przedsiębiorstwie, Wydawnictwo Uniwersytetu Marii Curie-Skłodowskiej, Lublin 2011, s. 36. 
Ministerstwo Infrastruktury i Rozwoju, Departament Programów Ponadregionalnych, Informacja o realizacji Strategii rozwoju społeczno-gospodarczego Polski Wschodniej do roku 2020 za rok 2014, Warszawa 2015.

OECD, Eurostat, Podręcznik Oslo. Zasady gromadzenia i interpretacji danych dotyczacych innowacji, Paris 2005.

Podkarpacki Klaster Energii Odnawialnej, O klastrze, http://energia.rzeszow.pl/index.php/ pomoc (dostęp 4.05.2015).

Portal Innowacji, Inteligentne specjalizacje a klastry, www.pi.gov.pl/PARP/chapter_86197. asp?soid=427438326EDF45A2935940951F4B3475 (dostęp 2.05.2015).

Portal Innowacji, Klastry w Polsce, www.pi.gov.pl/PARP/data/klastry/index.html (dostęp 4.05.2015).

Szafran J., Polska Wschodnia w polityce spójności Unii Europejskiej, w: Rozwój Polski Wschodniej. Ograniczenia i wyzwania, red. B. Jóźwik, M. Sagan, Difin, Warszawa 2012. Świętokrzysko-Podkarpacki Klaster Energetyczny - kontynuacja, http://klasteroze.it.kielce. $\mathrm{pl} /$ ?id=1 (dostęp 4.05.2015).

Urząd Marszałkowski Województwa Podkarpackiego, Projekt regionalnej strategii innowacji województwa podkarpackiego na lata 2014-2020 na rzecz inteligentnej specjalizacji (RIS3), Rzeszów 2013.

\title{
SYSTEMS OF SUPPORTING OF ECOLOGICAL INNOVATIONS IN THE EASTERN POLAND
}

\begin{abstract}
Eastern Poland is a region with the lowest level of economic development in Poland and one of the weakest in the European Union. Macro-region has become a subject of particular interest of regional policy, which requires further action, contributing to make up for backwardness and boost development. Smart, sustainable and inclusive growth of Eastern Poland is possible due to smart specializations of the region, which include eco-innovations. The aim of the article was to identify systems of supporting ecological innovations in the analyzed region and evaluation the possibility of using eco-innovation in building a competitive advantage of Eastern Poland.
\end{abstract}

Translated by Jolanta Korkosz-Gębska

Keywords: sustainable development, ecological innovations, Eastern Poland

JEL code: O30 
